\title{
Manufactured Object
}

National Cancer Institute

\section{Source}

National Cancer Institute. Manufactured Object. NCI Thesaurus. Code C97325.

A physical object created by hand or machine. 